\title{
Stability analysis of the Kosciuszko Mound using terrestrial laser scanner and numerical modelling
}

\author{
Elżbieta Pilecka*, and Karolina Tomaszkiewicz \\ Cracow University of Technology, Faculty of Civil Engineering, Cracow, Poland
}

\begin{abstract}
Landslides which form in anthropogenic soils are complicated from a geological engineering and geotechnical point of view. Each case requires a detailed investigation and the selection of effective reinforcements is a difficult project issue. The study presents the problem of the stability analysis of landslides occurring in the anthropogenic soils of the Kosciuszko Mound in Cracow. The previously performed protections are discussed to highlight their ineffectiveness and the current technical condition of the mound is also presented. By overlapping the results of displacement measurements made with a terrestrial laser scanner, a differential model of the terrain was created which made it possible to determine the size and direction of the deformation of the slopes of the mound and the tendencies for the development of landslide movements in this area. A cross-section, selected on the basis of the model, was numerically analysed using the finite element method (FEM) in the Midas GTS NX program. As a result of the analysis, the values of the displacements and strains occurring in the Mound were calculated. On the basis of the value of the safety factor obtained, it was also possible to assess the risk of landslide movements.
\end{abstract}

Keywords: Kosciuszko Mound, landslide, terrestrial laser scanning, numerical modelling

\section{Introduction}

Landslides formed from anthropogenic soils are complicated from a geological engineering and geotechnical point of view $[1,2]$. The slope stability analysis and the selection of a method for protection against these landslides are a difficult design issue. An important aspect is also the monitoring of landslides, which helps to enhance the observation of the deformation of the area with time, determine the range of the occurrence and the risk of landslide development [3]. Landslide monitoring may be realized through different kinds of geological engineering and geophysical methods, including telemetric methods [3-8]. Such deformations may also be modelled by numerical simulations $[9,10]$.

The purpose of the article is to present the results of studies carried out on the periodically active landslides at the Kosciuszko Mound, which is an anthropogenic soil mound. Based on

\footnotetext{
* Corresponding author: epilecka@pk.edu.pl
} 
the terrestrial laser scanner monitoring of the displacements of the Mound block, it was possible to locate the most deformed section. After that, it was subjected to a stability analysis in the Midas GTS NX program, the results of which allowed for the determination of the stability coefficient value and the risk of landslide movements.

The Kosciuszko Mound was built in the years 1820-1823 to commemorate the national hero Tadeusz Kosciuszko. It was built from soil covering the slope (loess formed in the form of dust and dust with loam). The mound is located on a thin layer of quaternary native soils. These soils are located on limestone, whose top is leaning towards the east, which also affects the direction of deformation. In the years 1850-1854, the base of the Mound was surrounded by a brick retaining wall and the chapel of St. Bronislawa was built in the western part of the wall [11].

Landslide processes on Kosciuszko Mound have taken place continuously from the moment it was built (the first mention dates from 1830-1840). Among the causes of the landslide processes in this area are the following: geological structure (the mound is made of an anthropogenic soil, mainly dusts and silty clays, having a tendency to settle under load and which are very sensitive to water - after dampening they show a decrease in strength parameters), the steep sloping angle of the slope of the Mound (around 46-51 ${ }^{\circ}$, at the base of the embankment, locally $40^{\circ}$ ), penetration of waters from precipitation and thaws into the embankment leading to the moistening and plasticizing of the soil that makes up the Mound, incorrect execution of reinforcements to the Mound. The soil conditions occurring in the Kosciuszko Mound and its surroundings, due to the presence of active geodynamic processes have been described as complicated [12].

The year 1997 was the turning point for landslides on the Kosciuszko Mound because of long-lasting heavy rains and floods. As a result, soil landslides were created, and cracks made it possible for water to penetrate into the Mound. The paths were completely destroyed, and the platform bent in a north-west direction, threatening to shift the commemorative boulder on top of the Mound into the chapel. The mound began to fall apart from the top, breaking in half - the state of the Mound was defined as the state of a construction disaster.

In the years 2000-2002, the largest renovation of the Kosciuszko Mound was made - its cone was reconstructed by completely dismantling the delaminated 9-meter part of the embankment. On the whole surface of the slope below, injection bolts were put into place and the surface was secured with a geomat. An HDPE membrane was placed on the exposed portion. The embankment was rebuilt from soil which had been mixed with soil from the dismantling of its central part and a gravel mix with geogrid reinforcement in the outer part. In 2002-2003, depth and surface monitoring networks were set up (inclinometers, piezometers).

Many protection and repair works (drainage system, protection in the form of nets, foil, a geomembrane, micropiles, soil anchors) undertaken over the years after each occurrence of a landslide have proven to be insufficient and ineffective. This may have been due to inaccurate geological diagnosis - all of the tests performed included only the surface layer of the embankment, no deeper layers of soil that make up the Mound were sampled, neither were the soil layers of native soils and rocks. Soil samples were taken via penetration, which caused a disturbance of the soil structure and humidity. In 2012, a detailed determination of the soil of the Kosciuszko Mound was performed. On the basis of these results, presented in [13], this article analyses the stability of the Mound's embankment and offers a proposal for the protection against landslides.

\section{Geotechnical condition of the Kosciuszko Mound}

Up to the last occurrence of a Kosciuszko Mound landslide which occurred in May 2010 due to heavy rains and floods, $50 \%$ of the Mound's area has been destroyed. Temporary 
safeguards in the form of geogrids, ropes and anchors were put in place, which slowed the landslide processes, but did not ensure the stability of the cone. The current technical condition of the Mound is described as bad. If no further measures are undertaken to secure the escarpment, there may be a construction disaster.

By area, the largest deformations have appeared on the southern and eastern sides. There are many traces of landslides, an unevenness of the surface of the embankment in the form of swellings of the soil, collapse of the soil in the vicinity of concrete bands surrounding the paths. Safety nets are exposed in several places. There are zones of dried grass on the surface of the slope, which shows the presence of areas with reduced humidity in these places.

The subsidence of the land has led in many places to moving concrete bands and damage to reinforced concrete drainage canals. Many transversal and longitudinal cracks are visible on the stone walking paths around the Mound. The damage described above constitutes a significant threat to the stability of the structure. The biggest problem is the possibility of penetration of water into the Mound. It causes a continuous deterioration in the geotechnical parameters of the soil, which may lead to further settlements and deformations of the mound.

In addition, the disruption of the drainage channels has been observed on the southern slope of the Mound - the damaged installation not only does not fulfil its function, it may also cause the Mound to be irrigated by water that has not been drained.

There are visible cracks in the balustrades surrounding the observation platform at the top of the Mound [phot.2]. There are cracks and other damage on the wall surrounding the Mound in the eastern part [phot.1]. On the northern side of the wall, there is a visible white coating on the bricks, in some places the bricks are slightly darker, which may be a sign of the increased humidity of the soil zones.

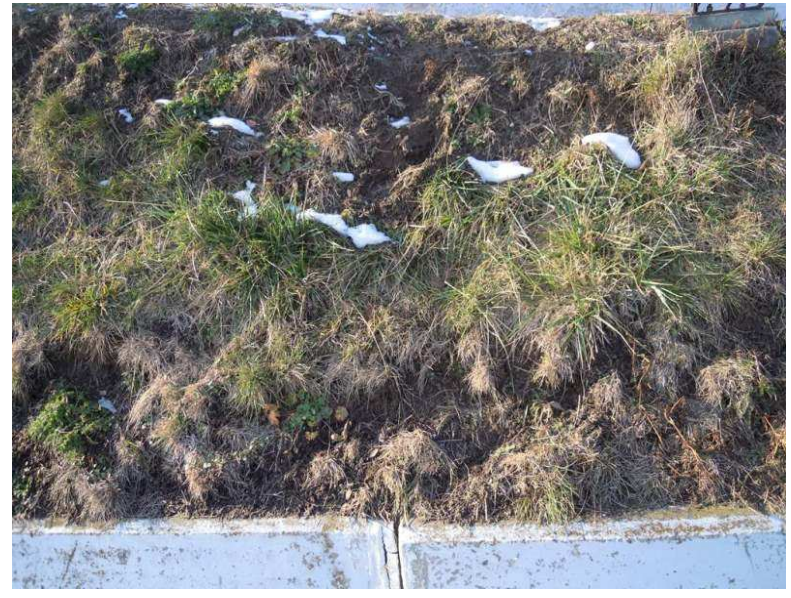

Phot. 1. Fragment of the landslide on the eastern slope of the Kosciuszko Mound [phot. K. Tomaszkiewicz].

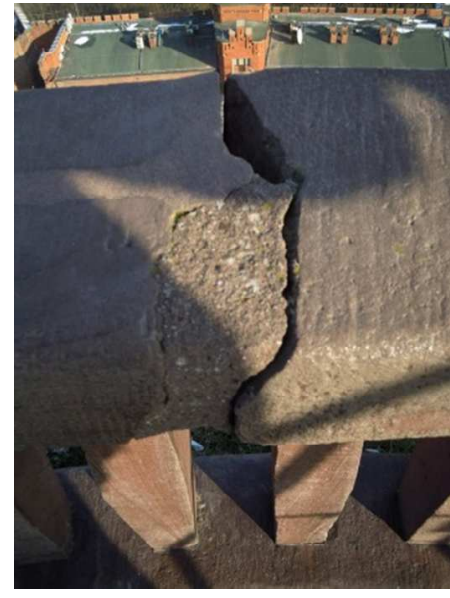

Phot. 2. Balustrade damage of the viewing platform of the Kosciuszko Mound [phot. K. Tomaszkiewicz].

\section{Deformation monitoring of the Kosciuszko Mound using terrestrial laser scanning}

Measurements of the area of the Kosciuszko Mound by a terrestrial laser scanner were performed twice, the measurements were performed over a year apart - in October 2015 and December 2016. By overlapping two numerical models of the surface area, it was possible to 
create a differential model, which showed that almost the whole corpus of the Kosciuszko Mound was deformed over a year between the measurements.

The slope is mainly deformed on the eastern side, which is slipping (displacement differences range from $-400 \mathrm{~mm}$ to $+400 \mathrm{~mm}$, the bottom part of the slope has deformed the most). On the south-eastern side, the largest displacements $(-200 \mathrm{~mm})$ occur near the lowest walking path and over the retaining walls. Slope increments on the southern side are on average $50 \mathrm{~mm}$, and in the lower part they vary from $-200 \mathrm{~mm}$ locally to even $+130 \mathrm{~mm}$. Large displacements may be observed near the drainage system - displacements even reach up to $+200 \mathrm{~mm}$. The Northeast, North and West sides are dominated by displacement increments of $+100 \mathrm{~mm}$. The part of the Mound below the top of the observation platform is the least deformed, local surface displacements occur only in the northern part (within +80 $\mathrm{mm}$ ). Slope displacements increase as you approach the base of the embankment.

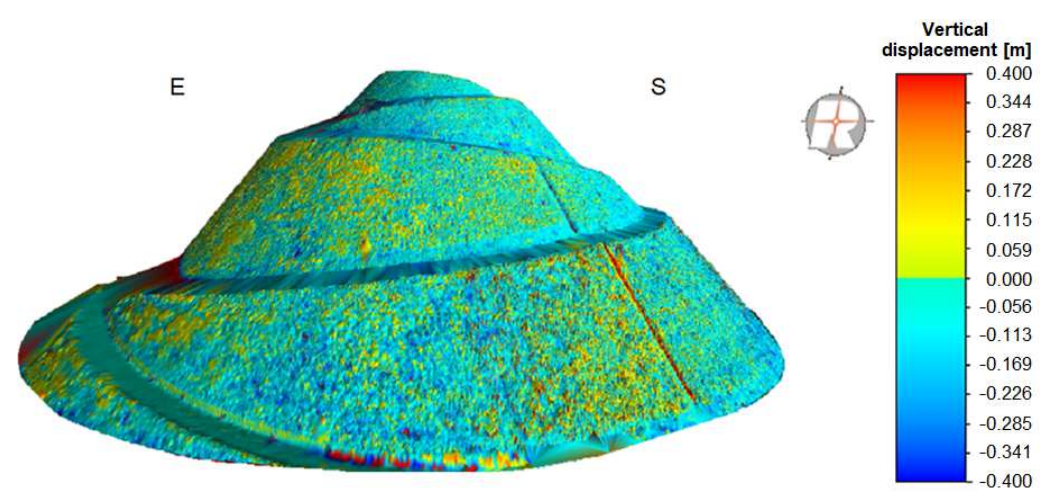

Fig. 1. Laser scanning differential model of the Kosciuszko Mound - vertical displacements of the south-west slope [14].

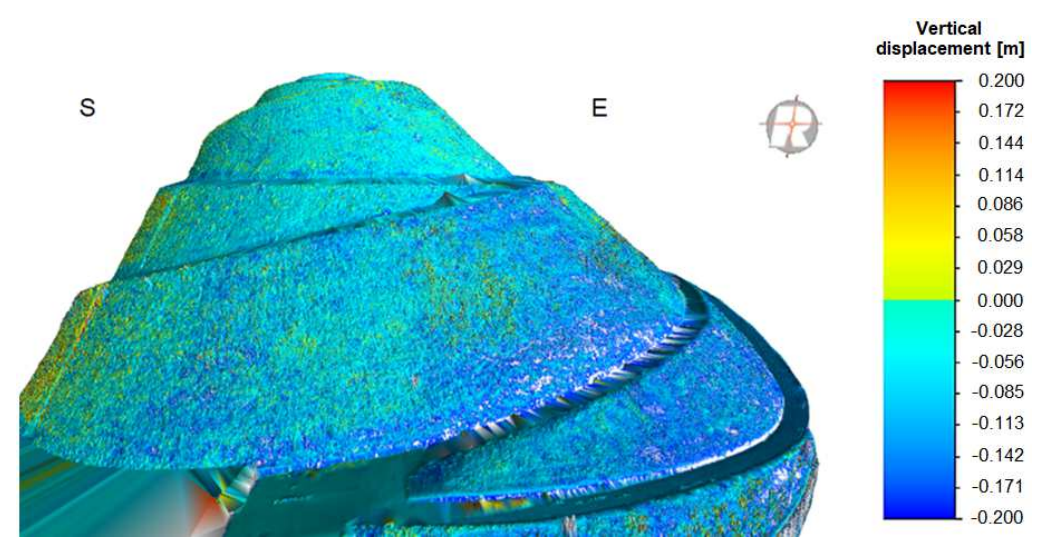

Fig. 2. Laser scanning differential model of the Kosciuszko Mound - vertical displacements of the south-eastern slope [14]. 


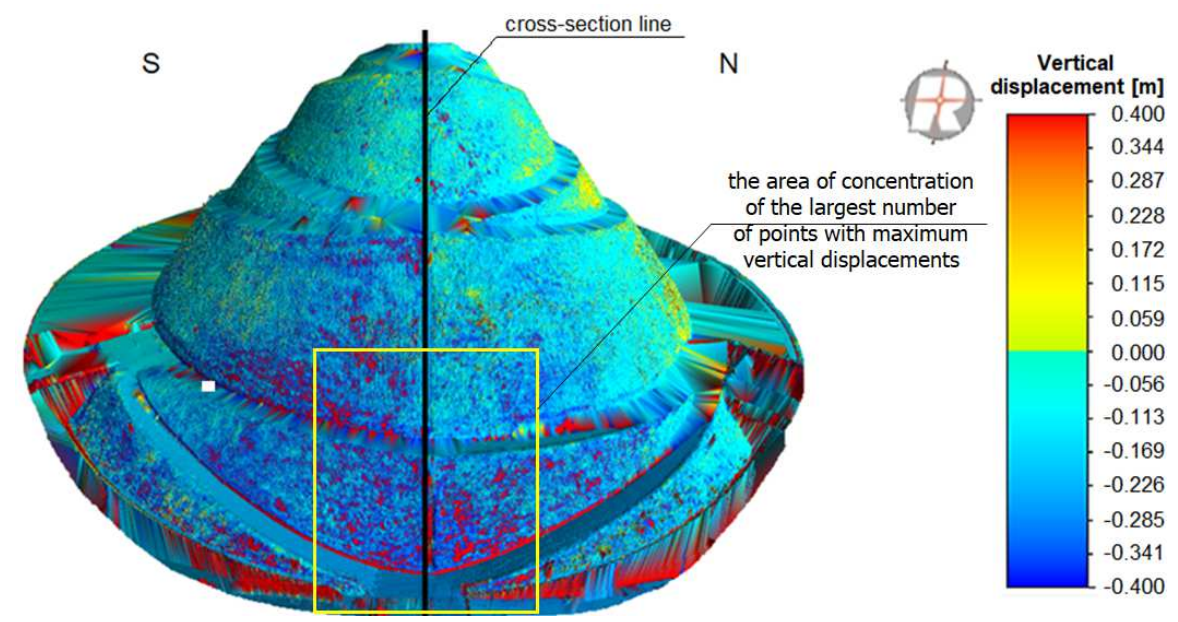

Fig. 3. Laser scanning differential model of the Kosciuszko Mound - vertical displacements of the eastern slope with a selection of the cross-sections adopted for numerical analysis (black line) [14].

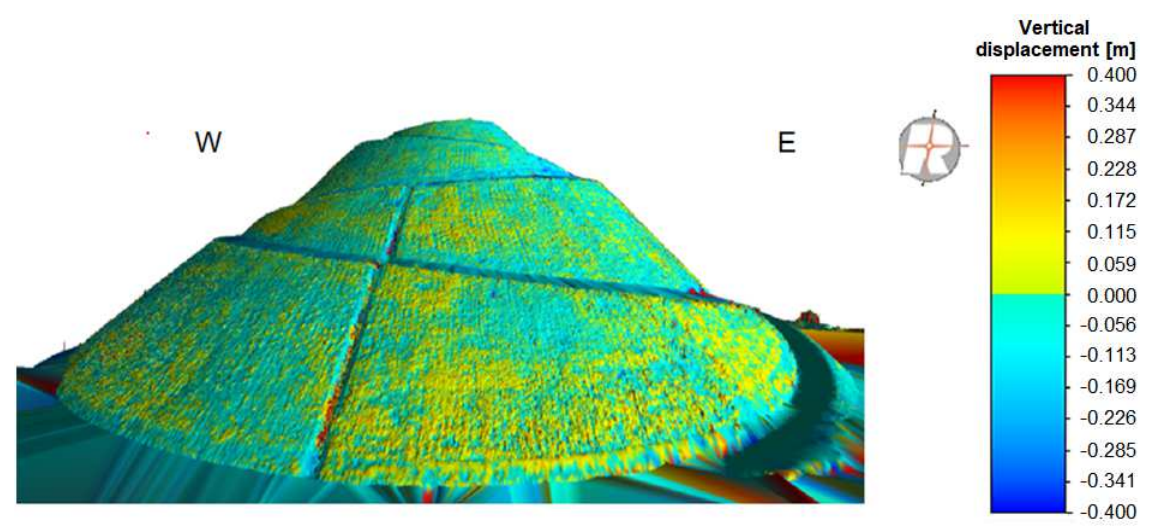

Fig. 4. Laser scanning differential model of the Kosciuszko Mound - deformations of the north slope [14].

\section{Stability analysis of the Kosciuszko Mound}

In order to determine the stability of the Kosciuszko Mound's embankment, numerical modelling was carried out [14]. A cross-section on the east-west line (Fig.3) was selected for the model. It was selected on the basis of the results of terrestrial laser scanner measurements, covering the most deformed areas (Fig. 3).

The stability of the Kosciuszko Mound's slope was checked using the Finite Element Method (FEM) in the MIDAS GTS NX program by making a two-dimensional model analysed in a plane strain conditions. The numerical analysis was carried out using shear strength reduction (SSR) technique. The Coulomb-Mohr model was adopted to describe the behaviour of the anthropogenic layers, and the elastic model for the limestone layer found in the base. The model was loaded with its own weight. The geometry of the model (Fig.5) and the types of soil that build the layers (Tab. 1) were selected on the basis of the results of geological surveys presented in [13]. 


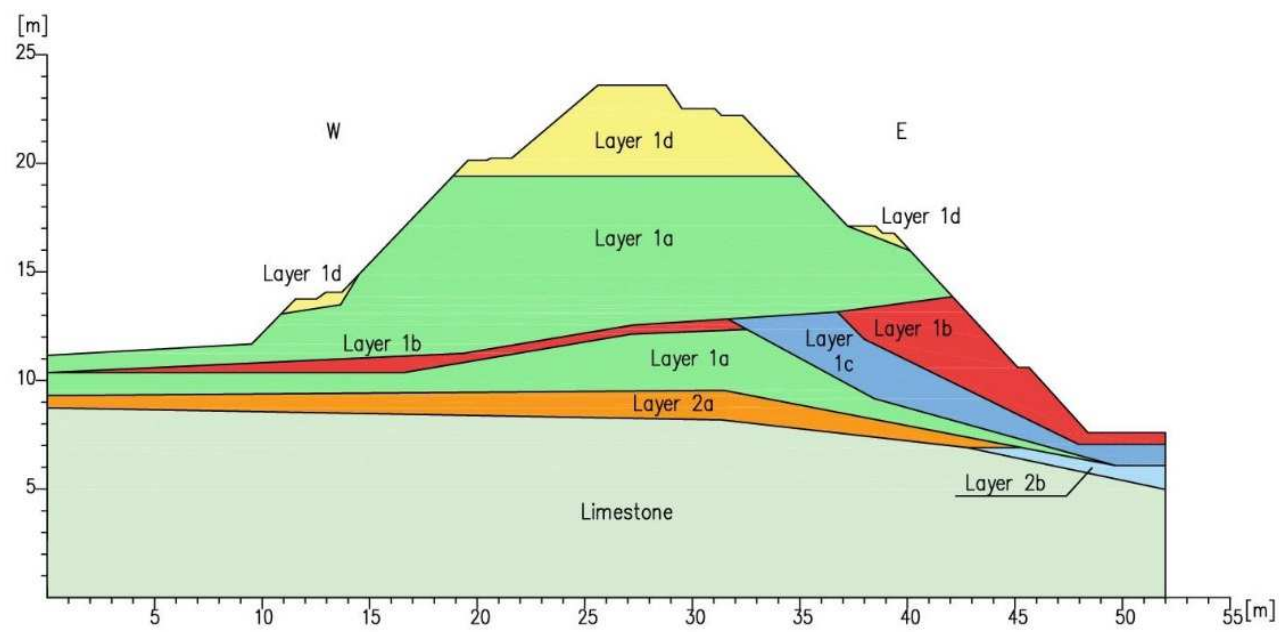

Fig. 5. Layout of W-E cross-sections adopted for the numerical model.

Tab. 1. Parameters adopted for the numerical analysis of soil parameters [14].

\begin{tabular}{|c|c|c|c|c|c|}
\hline $\begin{array}{c}\text { Layer } \\
\text { number }\end{array}$ & $\begin{array}{c}\text { Volumetric } \\
\text { density } \\
\rho\left[\mathrm{kg} / \mathrm{m}^{3}\right]\end{array}$ & $\begin{array}{c}\text { Angle of } \\
\text { internal } \\
\text { friction } \\
\phi\left[^{\circ}\right]\end{array}$ & $\begin{array}{c}\text { Cohesion } \\
\mathrm{c}[\mathrm{kPa}]\end{array}$ & $\begin{array}{c}\text { Young } \\
\text { modulus } \\
\text { E [MPa }]\end{array}$ & $\begin{array}{c}\text { Poisson ratio } \\
v[-]\end{array}$ \\
\hline $1 \mathrm{a}$ & 2149 & 24 & 33 & 30.2 & 0.08 \\
\hline $1 \mathrm{~b}$ & 2094 & 20 & 29 & 20.7 & 0.12 \\
\hline $1 \mathrm{c}$ & 2013 & 14 & 20 & 9.55 & 0.23 \\
\hline $1 \mathrm{~d}$ & 1960 & 30 & 0 & 28 & 0.25 \\
\hline $2 \mathrm{a}$ & 2123 & 25 & 32 & 29.2 & 0.08 \\
\hline $2 \mathrm{~b}$ & 2088 & 18 & 30 & 20.7 & 0.12 \\
\hline $\begin{array}{c}\text { Limest- } \\
\text { one }\end{array}$ & 2300 & - & - & 7445 & 0.25 \\
\hline
\end{tabular}

The width of the model is $52 \mathrm{~m}$, and the height of $23.5 \mathrm{~m}$ (at the highest point). The layers marked $1 \mathrm{a}-1 \mathrm{~d}$ are anthropogenic soils and layers $2 \mathrm{a}$ and $2 \mathrm{~b}$ are original soils. The upper part of the Mound is made of non-cohesive soils in the form of medium sand, medium sand with gravel, medium or fine sand with dust, sand with dust and gravel, gravel with sand and dust, gravel with sand. The lower part of the embankment is made of cohesive soils in the form of dusts, dusts with loams, clay with dust and sand, dust with clay and sand. The whole structure is based on limestone.

The results of the presented analysis refer to a situation with a critical stability. An analysis of slope stability with MIDAS GTS NX showed that the total factor of safety is 1.08 . The factor of safety is slightly greater than 1 , nevertheless this value is close to the critical value 1.00 (meaning the loss of stability) therefore it is necessary to control the development of landslide movements in this area.

The process of slope destruction starts in the lower part of the slope and then proceeds towards the top on the eastern side. The shear plane is clearly developed (fig. 6). The most 
serious damage to the slopes is in the lower part and decreases towards its top. The area covered by the occurrence of landslide movements and the direction of their development obtained on the basis of the analysis coincide with results of monitoring by a terrestrial laser scanner [16].
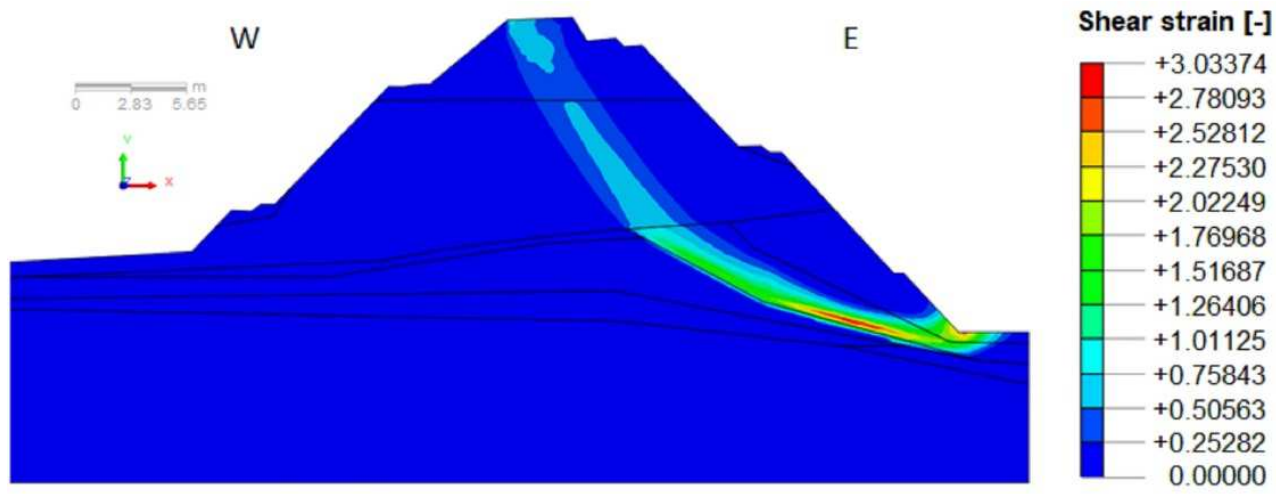

Fig. 6. Maximum shear strain for the WE cross section through the Kosciuszko Mound [14].

\section{Conclusions}

The example of landslides on the Kosciuszko Mound, which originated from anthropogenic soils, confirms how complicated are these kind of landslides. An important factor is the stability analysis based on detailed recognition of geological and engineering conditions occurring in the landslide area and the further terrestrial laser scanning of this area. On such a basis it is possible to analyse more effective the process of slope destruction.

Mound monitoring using terrestrial laser scanning has made it possible to create a differential terrain model. It is now possible to assess the development of the landslide process, determine the most deformed areas and the size of the displacements. On this basis, a representative cross section was selected, which was then subjected to numerical analysis.

Based on the study, it was found that:

- Results of numerical analysis confirmed measurements results made with a terrestrial laser scanner. It showed the most likely slide plane in the same place where the biggest deformations of the Kosciuszko Mound were observed.

- The Kosciuszko Mound priority is to temporarily secure or repair damage that threatens the stability of slopes. Among the works requiring immediate intervention, we can specify: protection of cracked walking paths, repair of the drainage system, filling the hollows, protection of balustrades surrounding the observation platform on the top of Kosciuszko Mound.

- The factor of safety determined by modelling is 1.08 and is close to the critical value 1.00. With further degradation of the ground structure, one can expect a reduction in the factor of safety, which means a loss of stability.

The presented study results may serve as a basis for a project to secure against these landslides. 


\section{References}

1. R. Kaczmarczyk, B. Olek, J. Stanisz, H. Woźniak, Z. Pilecki, Wplyw gruntów nasypowych na powstanie i rozwój osuwiska (Influence of dump soil on the initatiing and development of landslide), Przeglad Geologiczny 62(2-10), 594-600 (2014) (in Polish)

2. J. Stanisz, A. Borecka, Z. Pilecki, R. Kaczmarczyk, E3S Web Conf 24, 03002 (2017) doi: $10.1051 / \mathrm{e} 3$ sconf $/ 20172403002$

3. J. Kogut, E. Pilecka, and D. Szwarkowski, Analysis of landslide effects along a road located in the Carpathian flysch, Open Geoscience 2018 (in press)

4. E. Pilecka, D. Szwarkowski, E3S Web Conf 24, 01006 (2017) doi: $10.1051 /$ e3sconf/20172401006

5. R. Dikau, D. Brundsen, L. Schrott, M.-L. Ibsen, Landslide recognition: identification, movement and causes, Wiley, Chichester, UK (1996)

6. P. Harba, Z. Pilecki, Landslides 14, 1225-1233 (2016) doi: 10.1007/s10346-016-07792

7. Z. Pilecki, E3S Web Conf 24, 01001 (2017) doi: 10.1051/e3sconf/20172401001

8. Z. Pilecki, J. Ziętek, E. Pilecka, J. Karczewski, J. Kłosiński, The effectiveness of recognizing of failure surface of the Carpathian flysch landslide using wave methods. Proc. 13 ${ }^{\text {th }}$ European Meeting of Environmental and Engineering Geophysics "Near Surface 2007”, EAGE, 3-5 Sept. 2007, Istanbul, Turkey, P48 (2007)

9. E. Pilecka, M. Moskal, The influence of foundation for the initiation and growth of the landslidein the Carpathian Flysch, Technical Transactions, 114, 10, 113-121 (2018)

10. E. Pilecka, M. Moskal, Numerical analysis of landslide next regional route No. 975 in Borowa before and after securing it, Autobusy: technika, eksploatacja, systemy transportowe 19, 6, 202-206 (2018)

11. A. Wójcik (ed.), Kopiec Kościuszki i jego położenie geologiczne: atlas - przewodnik (Kosciuszko Mound and its geological location: atlas - guide), Urząd Miasta Krakowa. Wydział Kształtowania Środowiska, Krakow (2016) (in Polish)

12. Rozporządzenie Ministra Transportu, Budownictwa i Gospodarki Morskiej z dnia 27 kwietnia 2012 (Dz.U. $2011 \mathrm{nr}$ 163, poz. 981, ze zmianami) w sprawie ustalania geotechnicznych warunków posadowienia obiektów budowlanych (Regulation of the Minister of Transport, Construction and Maritime Economy of April 27, 2012 (Journal of Laws 2011 No. 163, item 981, as amended) on the determination of geotechnical conditions for the foundation of construction works)(in Polish)

13. Dokumentacja geologiczno-inżynierska dla rozpoznania podłoża, dla potrzeb opracowania zabezpieczenia obiektu stożka Kopca Kościuszki wraz z otoczeniem, zniszczonego przez aktywne osuwisko (Geological and engineering documentation for ground recognition, for the purpose of the protection of the Kosciuszko Mound's cone object with its surroundings, destroyed by an active landslide), Przedsiębiorstwo Geologiczne S.A., Krakow (2013)

14. K. Tomaszkiewicz, Analiza stateczności osuwiska okresowo czynnego na Kopcu Kościuszki $w$ Krakowie wraz z propozycja zabezpieczenia (Stability analysis of periodically active landslide on the Kosciuszko Mound in Cracow with proposal for reinforcement) engineering diploma thesis, Politechnika Krakowska, Krakow (2017) (in Polish) 
15. L. Wysokiński, Instrukcja ITB nr 424/2011. Ocena stateczności skarp i zboczy. Zasady doboru zabezpieczeń, (ITB instruction no. 424/2011. Eveluation of slope stability. Rules for selection of protection) Instytut Techniki Budowlanej, Warszawa (2011) (in Polish)

16. B. Wrana, N. Pietrzak, Slope stability estimation of the Kościuszko Mound in Cracow, Studia Geotechnica et Mechanica 37, 2, 93-101 (2015) 